\title{
点市中央地区の小学校通学路における石積み擁壁の地震ハザードマップ A ROUTE-TO/FROM-SCHOOL HAZARD MAP FOR STONE MASONRY WALLS IN KURE CITY BASED ON AN EARTHQUAKE SCENARIO
}

\author{
酒井久和*1, 田尾徹 郎*2, 宮 本 雄 樹*3, 正 岡 淳 也*4 \\ Hisakazu SAKAI, Tetsuro TAO, Yunki MIYAMOTO \\ and Junya MASAOKA
}

\begin{abstract}
We create a hazard map of Route-to/from-School for stone masonry walls in Kure city based on an earthquake scenario in order to indicate the danger zone for the public. The seismic stability of the stone masonry walls is evaluated using DDA (Discontinuous Deformation Analysis), which is a type of discrete element method and suits to solve the large displacements accompanying the discontinuous movements between blocks. First, we survey the detail of the stone masonry walls along the Route-to/from-School and examine the accuracy for simplifying the analytical model. Then, we estimate the seismic stability and possible dispersed areas of the stones from the collapsed walls based on an earthquake scenarios. Finally, we create a hazard map of Route-to/from-School for stone masonry walls in Kure city.
\end{abstract}

Keywords : Stone masonry walls, Hazard map, Discontinuous deformation analysis, Seismic assessment, Route-to/from-School, Scenario earthquake 石積み擁壁，ハザードマップ，不連続変形法，而震性評価，通学路，シナリオ地震

\section{1. はじめに}

石積み擁壁は，現地の転石を利用し，かつ，コンクリート壁と比 べて周囲の風景とも調和が取れる景観的にも良好な構造物であり， 国内外で多用されている。地震国である我が国において, 城壁など 数百年も渡り健全性を保持している石積久擁壁も存在するが, 2001 年芸予地震の呉市, 2005 年福岡県西方沖地震の玄界島においては, 多数の石積み擁壁が崩壊した。これらの地震では, 幸い人的被害は 小さかったが，石積み擁壁に接する道路では交通機能が長時間に渡 り損なわれた。生活に密着した石積み擁壁の崩壊は, 人命を危険に さらすだけでなく災害復旧やライフラインとしての交通路の遮断な ど大きな 2 次被害を誘引する可能性がある。特に小学校の通学路で は, 児童の通学時の安全性確保だけでなく, 小学校が地震時の避難 場所として指定されていることが多く，その役割を果たすために， 通学路の交通経路として機能を損なわないことが重要である。その ため, 予め耐震性の低い石積み擁壁に対して地震対策を行う必要が あるが，そのスクリーニング手法として現在，自治体ごとに簡易な 耐震性評価手法が採用されている。

田中ら ${ }^{1)}$ は，城郭など石積み擁壁の構築プロセスが確認される石 積夕に対し, 建設当時の石積み技術の水準から変位量を推定し, 安 定性を評価する手法を示している。渡嘉敷ら22 は, 石積夕擁壁の基 本的な動的安定挙動を検討するため, 石積み擁壁模型による動的載
荷実験を行い，図を用いた評価手法を提案している。田中ら ${ }^{33}$ は, 石積み擁壁の斜面高さ，傾斜角，背面土の土性值および石垣の物性 值等に対し, 円弧すべり法による評価手法を提案している。しかし， これらの簡易的な評価手法は，必ずしも十分な精度を有していない のが現状である。

一方, 詳細解析法として有限要素法（FEM）を用いて，石積み擁 壁の耐震性評価も行われている4),5)が, 崩壊に至るまでの安定性の評 価は行えるものの, 積み石の流動域検討などの大変形を伴う評価に は適していない。また，個別要素法（DEM）や剛体バネモデルでは パラメータの物理的意味合いが不明確で設定が解析ケースごとに異 なったり，落石のように物体の動きが速くなると解の安定性が得ら れなかったりするなどの問題点を有する。また，近年，不連続変形 法（DDA）による耐震性評価も行われている。池谷ら ${ }^{6}$ は石積み擁 壁の実物大モデルを用いた載荷実験の実験結果と DDA の解析結果 を比較し, DDA が定量的に実際の構造物の挙動を再現できること 示している。西山ら7は石積み擁壁の現地加振実験とDDAによるシ ミュレーションを行い, 石積み擁壁の挙動を DDA で精度良く追随 できることを示している。

吳市では 2001 年の芸予地震の際に石積み擁壁が多数崩壊し, 特 に中央地区の西側は斜面が急であるため被害が集中した。本研究で は小学校の通学路に未だ石積み擁壁が多数存在する呉市中央地区を

\footnotetext{
*1 広島工業大学工学部建築学科 准教授 $\cdot$ 博士 (工学)

*2 広島工業大学大学院 大学院生

*3 侏大林組

*4 (制フジ夕
}

Assoc. Prof., Dept. of Architecture, Faculty of Eng., Hiroshima Institute of Technology, Dr. Eng.

Graduate Student, Graduate School of Eng., Hiroshima Institute of Technology Obayashi Corporation

Fujita Corporation 


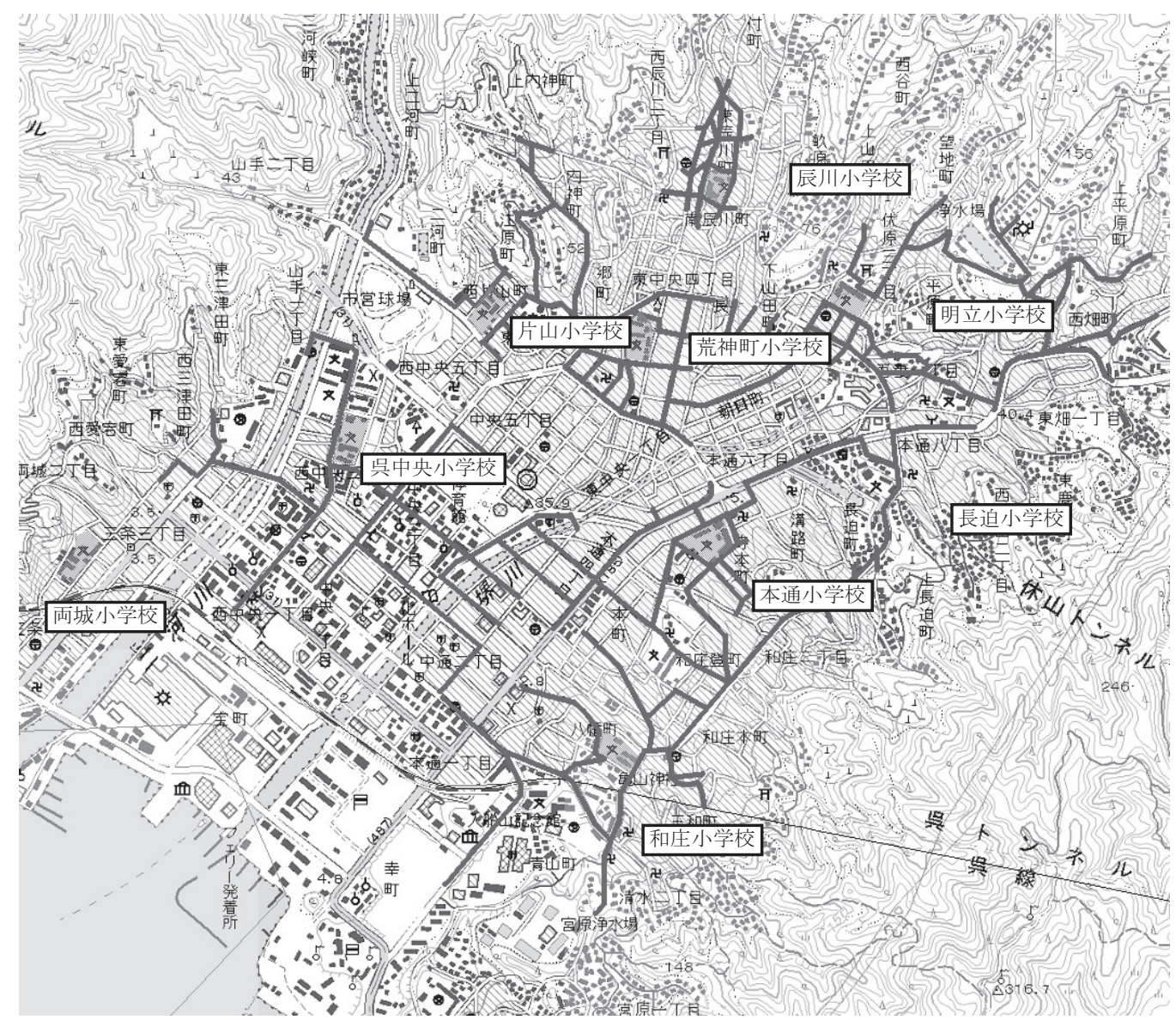

図 1 調查対象小学校及び主要通学路

対象に石積み擁壁の現地調查を実施し, 而震性評価に基づき, 石積 み擁壁の安全性, 交通経路としての機能性に関するハザードマップ を作成する。ここで，耐震性評価は，上述の不連続変形法（DDA） を採用する。2 章で石積み擁壁の現地調查, 3 章で DDA の解析モ デル簡略化の影響, 4 章で個々の石積み擁壁の耐震性評価, 5 章で はハザードマップについて示す。

\section{2. 現地調査}

石積み擁壁の耐震性評価は, 乶市中央地区の小学校の主要通学路 を対象とする。中央地区の小学校は 9 校で, 呉中央小学校, 本通小 学校, 和庄小学校, 辰川小学校, 長迫小学校, 荒神町小学校, 両城 小学校, 明立小学校, 片山小学校である。調查対象とした小学校お よび主要通学路域を図 1 に示す。ここで主要通学路は, 遣市教育委 員会からの情報を基に抽出し, 図中に太線で表示寸る。ただし, 両 城小学校については通学路を指定していないため, 調查は正門, 通 用門に面した石積み擁壁のみを対象とした。

現地調查では, 石積夕擁壁の高さ, 平均傾斜角, 構造種別を調查 するとともに, 避難経路である通学路の使用性の有無を調べるため に，石積みに接する道路の幅員を計測する。ただし，石積み擁壁の 高さ, 平均傾斜角は写真測量, 構造種別は目視で行い, 道路幅員は 歩道と車道を含むものとしてメジャー計測で行った。

調査の結果, 中央地区の小学校の主要通学路域には, 石積み擁壁 が 81 箇所あった。その計測結果を表 1(a), (b)に示す。また, 石積 み擁壁の高さ, 平均傾斜角, 道路幅員の分布を図 2 図 4 に示寸。
表 1 に示すように，81 箇所の石積み擁壁のうち, 練積み構造は 48 箇所, 空積み構造は 9 箇所, 混在は 8 箇所, 不明は 16 箇所ある

表 1 吳市中央地区石積み擁壁の概要 (a)

\begin{tabular}{|c|c|c|c|c|c|c|c|c|}
\hline 学校名 & 番号 & 幅員 (m) & 高さ $(\mathrm{m})$ & 平均傾斜角 ( $\left.{ }^{\circ}\right)$ & & 䨪造 $\sigma$ & 種類 & 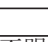 \\
\hline & 1 & 4.1 & 5.7 & 72.0 & & & 0 & \\
\hline 吳中央小 & 2 & 4.4 & 5.1 & 76.0 & & & & 0 \\
\hline & 3 & 19.3 & 5.4 & 67.5 & & & & 0 \\
\hline & 4 & 5.0 & 3.8 & 77.0 & 0 & & & \\
\hline & 5 & 5.3 & 2.1 & 76.3 & 0 & & & \\
\hline & 6 & 3.4 & 2.6 & 76.5 & 0 & & & \\
\hline & 7 & 3.1 & 2.6 & 71.5 & 0 & & & \\
\hline 本通小 & 8 & 5.0 & 3.5 & 78.7 & & & 0 & \\
\hline & 9 & 5.5 & 4.8 & 72.8 & 0 & & & \\
\hline & 10 & 5.3 & 3.5 & 79.0 & & & & 0 \\
\hline & 11 & 2.7 & 3.8 & 80.0 & 0 & & & \\
\hline & 12 & 3.2 & 3.2 & 79.4 & 0 & & & \\
\hline & 13 & 8.6 & 3.2 & 71.3 & 0 & & & \\
\hline & 14 & 8.4 & 3.2 & 66.2 & 0 & & & \\
\hline & 15 & 6.7 & 3.0 & 64.6 & 0 & & & \\
\hline & 16 & 4.2 & 2.6 & 73.9 & & 0 & & \\
\hline 和广古 & 17 & 4.0 & 3.3 & 79.0 & 0 & & & \\
\hline 机生小 & 18 & 1.6 & 3.4 & 77.4 & & & & 0 \\
\hline & 19 & 5.2 & 4.0 & 80.8 & 0 & & & \\
\hline & 20 & 5.1 & 2.6 & 77.0 & 0 & & & \\
\hline & 21 & 7.6 & 3.2 & 73.1 & 0 & & & \\
\hline & 22 & 7.7 & 2.2 & 73.4 & 0 & & & \\
\hline & 23 & 4.5 & 3.3 & 80.3 & & & & 0 \\
\hline 辰川小 & 24 & 2.4 & 1.8 & 85.1 & & & & 0 \\
\hline & 25 & 3.2 & 2.6 & 77.9 & & & 0 & \\
\hline & 26 & 3.5 & 1.9 & 77.3 & 0 & & & \\
\hline
\end{tabular}


表 1 吳市中央地区石積み擁壁の概要 (b)

\begin{tabular}{|c|c|c|c|c|c|c|c|c|}
\hline \multirow{2}{*}{ 学校名 } & \multirow{2}{*}{ 番号 } & \multirow{2}{*}{ 幅員 (m) } & \multirow{2}{*}{ 高さ (m) } & \multirow{2}{*}{ 平均傾斜角 $\left(^{\circ}\right)$} & \multicolumn{4}{|c|}{ 構造の種類 } \\
\hline & & & & & 練積 & 空積 & 混在 & 不明 \\
\hline \multirow{8}{*}{ 長迫小 } & 27 & 11.3 & 7.1 & 79.4 & O & & & \\
\hline & 28 & 4.6 & 3.8 & 69.7 & $\bigcirc$ & & & \\
\hline & 29 & 7.1 & 3.7 & 67.5 & 0 & & & \\
\hline & 30 & 7.6 & 2.9 & 81.8 & O & & & \\
\hline & 31 & 3.1 & 3.9 & 79.1 & $\bigcirc$ & & & \\
\hline & 32 & 9.0 & 3.4 & 81.6 & 0 & & & \\
\hline & 33 & 5.6 & 6.1 & 72.7 & 0 & & & \\
\hline & 34 & 6.6 & 2.9 & 77.7 & 0 & & & \\
\hline \multirow{8}{*}{ 荒神町小 } & 35 & 4.7 & 3.2 & 79.8 & & $\mathrm{O}$ & & \\
\hline & 36 & 3.7 & 4.2 & 77.0 & & & 0 & \\
\hline & 37 & 2.6 & 3.3 & 70.8 & & 0 & & \\
\hline & 38 & 2.7 & 3.3 & 82.4 & & & 0 & \\
\hline & 39 & 2.7 & 2.2 & 82.4 & & & & $\mathrm{O}$ \\
\hline & 40 & 2.3 & 2.3 & 78.3 & & & & 0 \\
\hline & 41 & 3.3 & 4.1 & 78.6 & $\bigcirc$ & & & \\
\hline & 42 & 2.9 & 2.0 & 77.7 & 0 & & & \\
\hline \multirow{2}{*}{ 両城小 } & 43 & 5.5 & 4.8 & 75.1 & & $\mathrm{O}$ & & \\
\hline & 44 & 5.8 & 3.5 & 76.2 & $\bigcirc$ & & & \\
\hline \multirow{24}{*}{ 明立小 } & 45 & 3.4 & 2.1 & 81.6 & $\bigcirc$ & & & \\
\hline & 46 & 2.3 & 2.8 & 75.3 & & $\bigcirc$ & & \\
\hline & 47 & 2.9 & 1.8 & 80.7 & & $\bigcirc$ & & \\
\hline & 48 & 2.8 & 2.6 & 74.8 & $\bigcirc$ & & & \\
\hline & 49 & 2.5 & 4.8 & 72.3 & & & & 0 \\
\hline & 50 & 3.5 & 3.7 & 80.3 & 0 & & & \\
\hline & 51 & 3.8 & 1.9 & 82.6 & 0 & & & \\
\hline & 52 & 3.2 & 2.8 & 79.5 & & & & 0 \\
\hline & 53 & 3.3 & 3.1 & 81.6 & & & & 0 \\
\hline & 54 & 3.6 & 2.7 & 84.9 & $\mathrm{O}$ & & & \\
\hline & 55 & 5.0 & 2.4 & 81.6 & 0 & & & \\
\hline & 56 & 4.8 & 2.1 & 77.9 & $\bigcirc$ & & & \\
\hline & 57 & 3.4 & 5.7 & 77.6 & 0 & & & \\
\hline & 58 & 2.6 & 2.8 & 79.7 & $\bigcirc$ & & & \\
\hline & 59 & 2.9 & 2.9 & 76.0 & 0 & & & \\
\hline & 60 & 4.1 & 5.1 & 78.5 & & & $\bigcirc$ & \\
\hline & 61 & 3.7 & 1.8 & 65.3 & & $\bigcirc$ & & \\
\hline & 62 & 5.9 & 3.7 & 67.4 & 0 & & & \\
\hline & 63 & 4.1 & 3.9 & 78.9 & & & & 0 \\
\hline & 64 & 4.4 & 3.0 & 82.2 & & & & 0 \\
\hline & 65 & 2.9 & 2.9 & 76.0 & 0 & & & \\
\hline & 66 & 3.0 & 2.1 & 79.9 & $\bigcirc$ & & & \\
\hline & 67 & 3.3 & 2.3 & 83.3 & & & & 0 \\
\hline & 68 & 7.1 & 2.2 & 69.4 & & 0 & & \\
\hline \multirow{13}{*}{ 片山小 } & 69 & 18.5 & 2.5 & 75.2 & 0 & & & \\
\hline & 70 & 5.0 & 3.7 & 71.3 & 0 & & & \\
\hline & 71 & 4.6 & 3.3 & 82.3 & 0 & & & \\
\hline & 72 & 4.7 & 5.1 & 74.7 & & & & 0 \\
\hline & 73 & 4.5 & 4.0 & 83.4 & $\bigcirc$ & & & \\
\hline & 74 & 4.0 & 1.9 & 80.5 & $\bigcirc$ & & & \\
\hline & 75 & 4.1 & 2.3 & 75.3 & & & 0 & \\
\hline & 76 & 4.8 & 2.8 & 74.8 & 0 & & & \\
\hline & 77 & 4.2 & 2.2 & 75.4 & 0 & & & \\
\hline & 78 & 3.5 & 3.3 & 75.4 & 0 & & & \\
\hline & 79 & 3.5 & 2.9 & 80.6 & & & & 0 \\
\hline & 80 & 4.0 & 5.2 & 76.8 & & 0 & & \\
\hline & 81 & 3.9 & 3.4 & 69.4 & & & 0 & \\
\hline
\end{tabular}

ことが分かった。ただし, 数箇所の練積み構造の石積み擁壁に充填 してあるモルタルのはがれた部分から瞀くと, 中が空洞であったた め, 練積夕構造の機能を果たせていない。すなわち, 外見上は練積 み構造のようであるが, 強度の面からは空積み構造に近い状態であ ると考えられる。また, 建築基準法施行令（2001）8)では, 高さ $2 \mathrm{~m}$ を越える石積み擁壁は練積み構造にしなければならないという規定 があるが, No.43 やNo.80 のように約 $5 \mathrm{~m}$ の高さを有する石積み擁

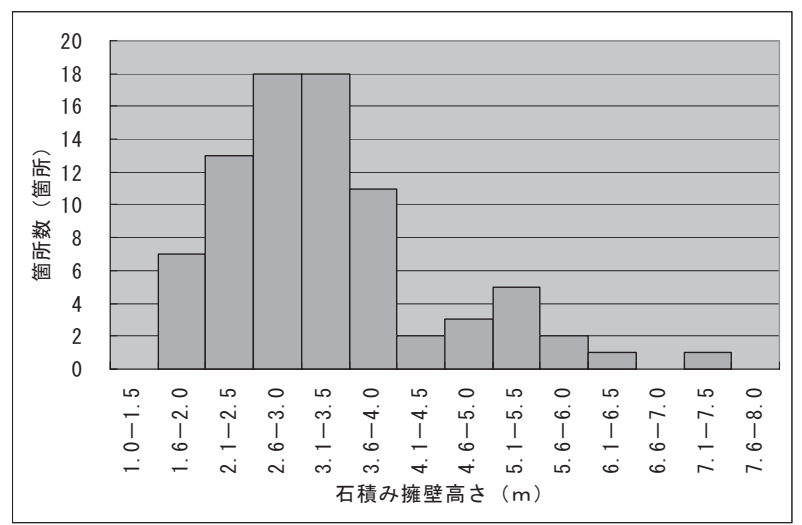

図 2 吳市中央地区における石積夕擁壁の高さ分布

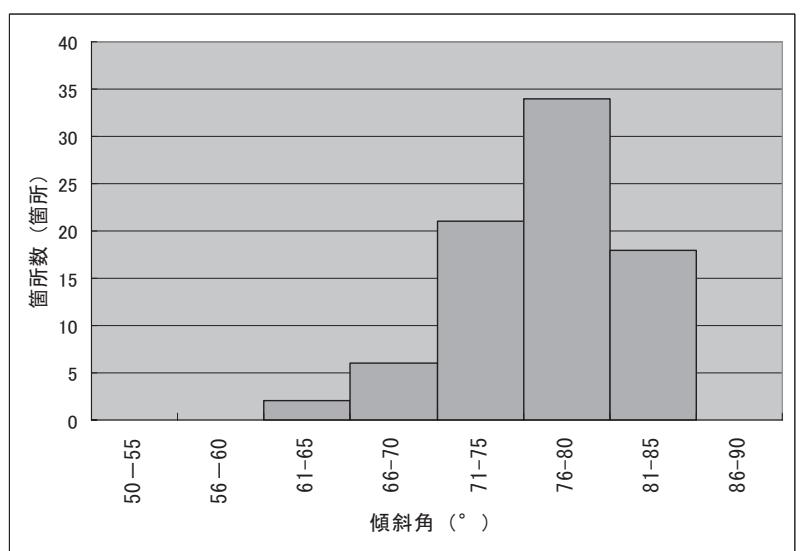

図 3 只市中央地区における石積夕擁壁の傾斜角分布

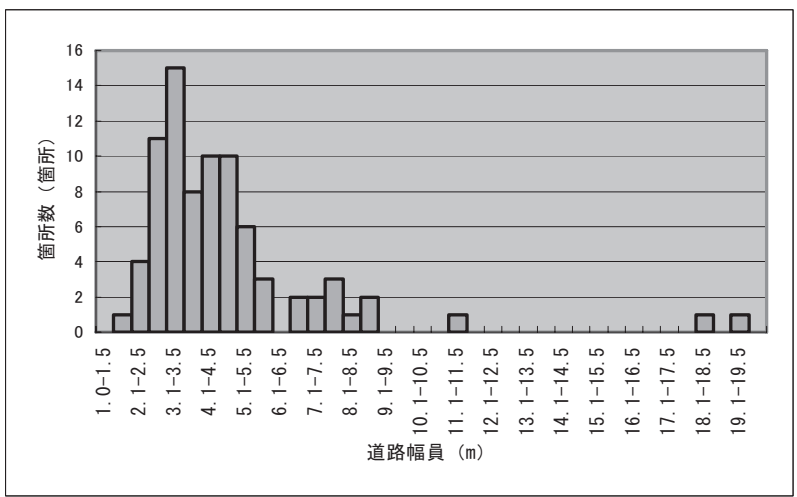

図 4 呉市中央地区における石積み擁壁前の道路幅員分布

壁で空積み構造のものも既存している。

図 2 より, 石積夕擁壁の高さは，2m〜 $4 \mathrm{~m}$ のものが多く, 最大 $7.1 \mathrm{~m}$ の擁壁が存在する。石積夕擁壁の勾配は, 図 3 に示すように $70^{\circ} \sim 85^{\circ}$ のものがほとんどで全体の 90\%を占める。また, 道路幅 員に関しては, 図 4 より, 約 $19 \mathrm{~m}$ の幅員を有する道路もあるが, ほとんどが $6 \mathrm{~m}$ 以下で， $3 \mathrm{~m}$ 以下の道路も $20 \%$ 含まれている。この うち, No.49 のように擁壁高さ $4.8 \mathrm{~m}$ に対して幅員 $2.5 \mathrm{~m}$ と比較的と 狭く感じられる通学路も存在する。

\section{3.モデル簡略化の影響}

DDA では要素数が多くなると解が不安定となる現象が発生する ことがある。理由として詳細は赤尾の研究9)をされたいが, 要約を 
下記に示す。

DDA 解析においては, 要素間に接触バネを導入することで, 要 素間の貫入を防止する。この際接触バネの剛性がペナルティ係数で あり，ペナルティ係数は，ブロック間の貫入をゼロとするために， 貫入のポテンシャルエネルギーを最小 2 乗法により求める際の係数 である。したがって, ペナルティ係数に物理的な意味はない。詳細 は文献10)を参照されたいが, ペナルティ係数の大きさは, 多数のブ ロック (要素数) モデルに対して, ある一つの要素に対して適切で あっても, 他の要素に対しては（当要素に載荷される荷重の相違な どにより）適切にはならない問題が, 多数要素のモデルには発生す る場合がある。適切な解が得られるペナルティ係数の範囲は狭い範 囲となる。要素数が少ない場合は, どこかの要素に着目して係数值 を設定すればモデル全体に対して安定した解が得られるが，ペナル ティ係数の設定が要素ごとに設定できる手法でない限り, 多数の要 素からなるモデルでは, 狭い許容範囲の中から最適なペナルティ係 数を探索する試行が必要となる。

ただしこの場合でも，モデルを解析対象に対して忠実なものにす るために, 質量の大きな要素と小さな要素の組み合わせになる解析 モデルの場合は，同じくペナルティ係数をどれかの要素に着目して 設定しても, 他の要素に対して適切になるとは限らない。数学的に 要素ごとに係数の值を設定することは不可能であり, 多数要素のモ デルでは, 係数の最適值を試行で繰り返して求める事よりも, 解析 対象の再現性を阻害しない範囲で要素数を低減して解析することが 妥当となる。

本研究でも, 表 1 の各石積み擁壁の耐震性の検討を進めると和庄 小学校（No.16, 17）で解析の不安定現象が発生した。そのため, 以後の石積み擁壁の耐震性評価のために, 解析モデルの簡略化の検 討を行う。

\section{1 解析モデル}

解析モデルの簡略化の検討を行う際の解析対象構造物として, 和 庄小学校 $($ No.16, 17) の石積み擁壁を採用する。積み石は現地調

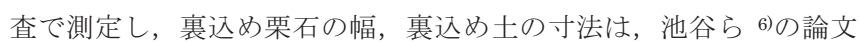
を参考に設定した。また，上述のように DDA では要素数の制限を 受けるため，裏込め栗石，裏込め土のメッシュ間隔を $0.15 \mathrm{~m} ， 0.5 \mathrm{~m}$ とし, 裏込め栗石, 裏込め土の要素分割は, 森川らの研究 ${ }^{11)}$, およ び，崩壊の生じ易さと簡便さを勘案して水平と $\pm 45^{\circ}$ となる方向で 分割を行った。解析モデルは, 石積み擁壁後方の地山を含む解析モ

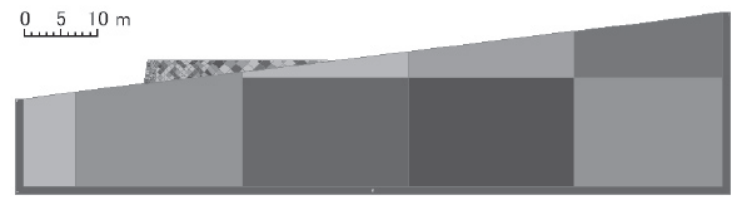

(a) 和庄小学校 (No.16)

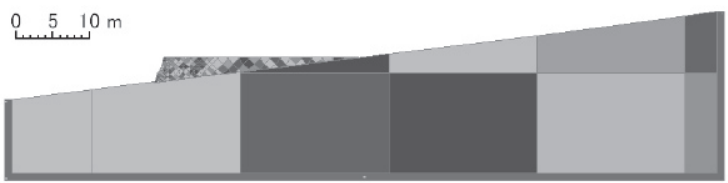

(b) 和庄小学校 (No.17)

図 5 石積み擁壁後方を含む解析モデル図（標準モデル）

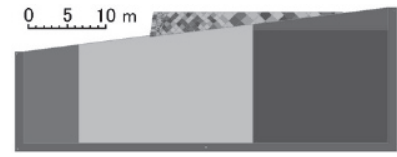

(a) 和庄小学校（No.16）

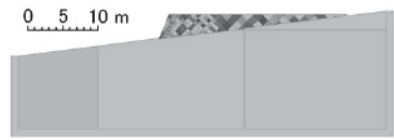

(b) 和庄小学校 (No.17)

図 6 後方地山を削った解析モデル図

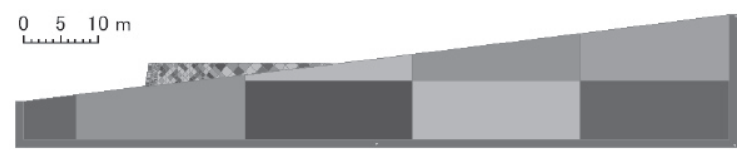

(a) 和庄小学校 (No.16)

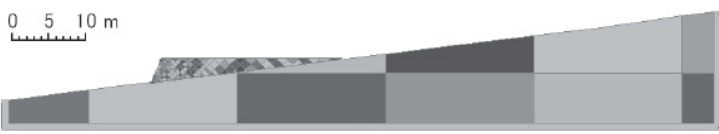

(b) 和庄小学校 (No.17)

図７下部地山を削った解析モデル図

表 2 材料特性パラメータ

\begin{tabular}{|l|c|c|c|c|c|}
\hline \hline & 積み石 & \multicolumn{1}{c|}{ 裹込栗石 } & \multicolumn{1}{c|}{ 込め土 } & \multicolumn{1}{c|}{ 地山 } & 基盤 \\
\hline 単位体積重量 $\left(\mathrm{kN} / \mathrm{m}^{3}\right)$ & 26 & 26 & 19 & 19 & 19 \\
\hline ヤング率 $\left(\mathrm{kN} / \mathrm{m}^{2}\right)$ & $1.0 \times 10^{7}$ & $1.0 \times 10^{7}$ & $3.0 \times 10^{4}$ & $1.0 \times 10^{6}$ & $8.3 \times 10^{4}$ \\
\hline ポアソン比 & 0.25 & 0.25 & 0.3 & 0.3 & 0.3 \\
\hline 内部摩擦角 $\left({ }^{\circ}\right)$ & 45 & 45 & 33 & 33 & 33 \\
\hline 粘着力 $\left(\mathrm{kN} / \mathrm{m}^{2}\right)$ & 0 & 0 & 23 & 23 & 23 \\
\hline 引張強度 $\left(\mathrm{kN} / \mathrm{m}^{2}\right)$ & 0 & 0 & 0 & 0 & 0 \\
\hline
\end{tabular}

デル（標準モデル）, 後方の地山を削った解析モデル, 石積み擁壁下 部の地山を削った解析モデルの 3 パターンとし, それぞれ, 図 5〜 図 7 に示寸。ちなみに, 標準モデルは, 解の不安定性が生じないよ うに要素数を低減したモデルであり, その要素数は, 和庄小学校の No.16 が 247, No.17 が 378 である。

\section{2 解析パラメータ}

DDA には構造物の物性を示すパラメータと DDA 特有のパラメー タが必要となる。このうち, 石積み擁壁の物性パラメータは, 既往 の検討事例 7)を参考に表 2 のように設定する。

次に DDA 特有のパラメータとして粘性係数, 前述のペナルティ 係数がある。ペナルティ係数は, 静的な解析の場合, 一般にブロッ クのヤング率より大きな值を用いる。この值がヤング率より小さい 場合には収束が悪くなり, ときには, ブロックどうしが重なって, ペナルティ係数が効かなくなる場合がある。ただし，落石のような 動的な運動が卓越するモデルでは, ペナルティ係数を大きくすると ブロックどうしの反発力が大きくなり，過剩な跳躍運動になること があるため, ヤング率と同様の值が推奨されると示されている。本 研究では，積み石，裏込め栗石，裏込め土の崩壊が想定され，崩れ た積み石や裏込め栗石は地山上を流動すると考えられることから， ヤング率が積み石および裹込め栗石と裏込め土の間の值である地山 の值を参考にペナルティ係数を設定する。

一方，粘性係数については，関ら ${ }^{12)}$ の論文で，落石解析に DDA 
を適用し，斜面から落石が跳躍する際のエネルギーロスや飛翔中の 空気抵抗を解析に組み込むために, DDA に一律の粘性係数が導入 されている。また, 粘性係数を $0.05,0.10,0.15$ とした 3 ケースで 数值シミュレーションを行い, ビデオ解析結果との比較により, 0.10 が合致していること示している。さらに, 立花ら ${ }^{13}$ は, 落石対策工 事の設計に際し，DDA を用いて粘性係数を $0.05 ， 0.10 ， 0.15$ とし て解析し，0.10のケースがもっとも現地の落石状況と適合すること を示している。よって, 本研究においても, 粘性係数は 0.10 に設定 する。

計算時間間隔に関して DDA では, 各計算ステップにおける貫入 量が許容值を超えないように計算時間間隔を細分化されるが，解析 精度を確保するため, 初期值として FEM の非線形解析で使用頻度 の多い $10^{-3}$ オーダーよりも 1 オーダー小さな時間間隔を採用する。

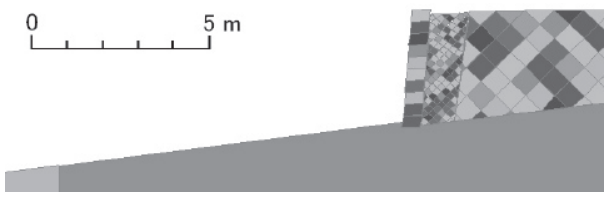

（a）標準モデル

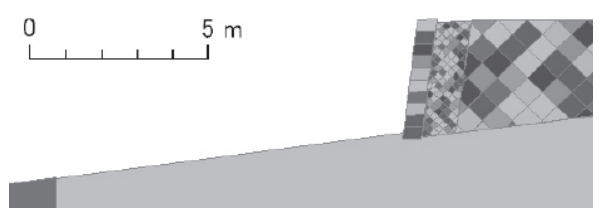

（b）後方地山を削ったモデル

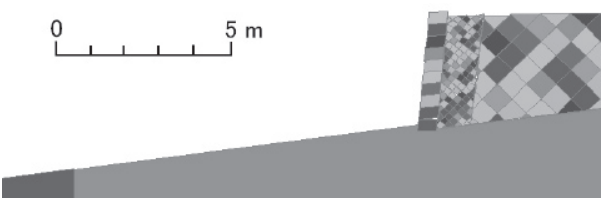

（c）下部地山を削ったモデル

図 9 和庄小学校（No.16）の残留変形図

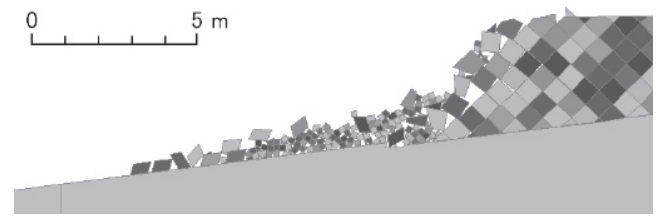

(a) 標準モデル

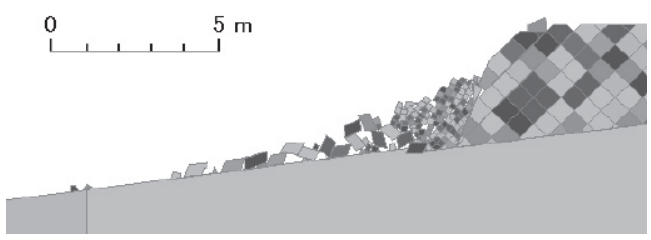

（b）後方地山を削ったモデル

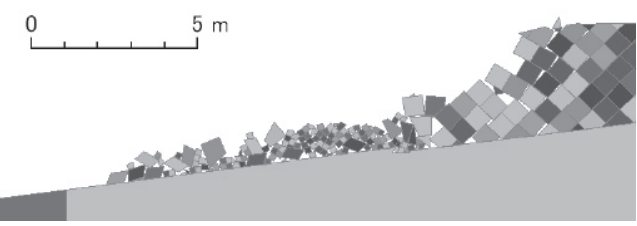

（c）下部地山を削ったモデル

図 10 和庄小学校 (No.17) 残留変形図
表 3 解析パラメータ

\begin{tabular}{|l|c|}
\hline ペナルティ係数 $\left(\mathrm{kN} / \mathrm{m}^{2}\right)$ & $1.0 \times 10^{6}$ \\
\hline 粘性係数 & 0.10 \\
\hline 計算時間間隔 $(\mathrm{s})$ & 0.0001 \\
\hline
\end{tabular}

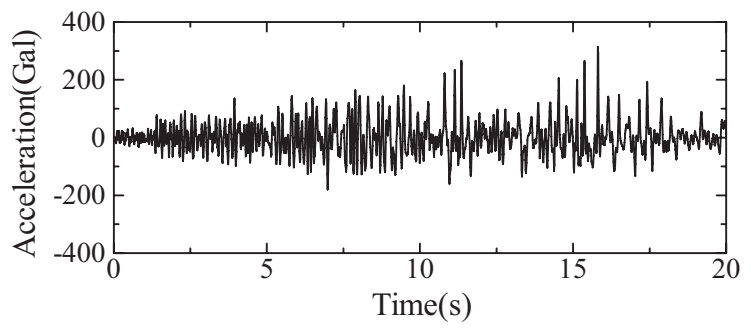

図 8 人力加速度波形

本解析で用いた解析パラメータを表 3 に示す。

\section{3 想定地震動}

本研究では, 震源の規模がマグニチュード 7.25 , 倉橋島沖合の安 芸灘に震源域を有する地震14)を想定する。この地震は, 明治 38 年 芸予地震規模の地震が再来するケースとし, M7.25 と設定されてい る。ちなみに, この地域に発生する地震は, 西日本へもぐり込むフ イリピン海プレート先端部の地下約 $50 \mathrm{~km}$ の深部で発生するプレー 卜内地震と考えられており，これまで 50 〜 100 年の周期で M7 クラ スの地震が発生している。

地震動は，上述の想定芸予地震による各石積み擁壁位置での加速 度応答スペクトル（500mメッシュ）14)に適合させた地表面波を使 用する。この際，適合波の位相は，芸予地震（2001）による K-NET 点での記録15)のうち，石積み擁壁断面方向に応じて，地震波の水平 成分（NS または EW）の位相特性を採用する。ただし，採用する 地震動は，NS，EW 方向から擁壁断面方向に近い成分とした。例と して, 和庄小学校の石積夕擁壁（No.16，17）位置での, 入力加速 度波形（EW）を図 8 に示す。ただし，DDAの解析には，解析時 間の軽減のため, 15〜35 秒の 20 秒間の振幅のみを使用している。

\section{4 結果と考察}

DDA による地震応答解析の結果，和庄小学校 (No.16, 17)の解 析終了時刻における残留変形図を図 9, 図 10 にそれぞれ示す。

和庄小学校（No.16）では，図 9 に示すように，標準モデル，後 方の地山を除いた解析モデル，下部地山を除いた解析モデルの 3 種 類の石積み擁壁がともに，はらみ出しを起こし，かつ，積み石のせ り出しが約 $20 \mathrm{~cm}$, 裏込め栗石の沈下が約 $15 \mathrm{~cm}$ とほぼ同様の変形 を生じた。また，和庄小学校（No.17）でも，図 10 に示すように, 標準モデル，後方の地山を削った解析モデル，下部地山削った解析 モデルの 3 種類の石積み擁壁が共に崩壊するという而震性評価が得 られた。ここで，下部地山を削ったモデル(c)は，標準モデル(a)と後 方地山を削ったモデル(b)に比べ裏込め栗石, 裏込め土ともに, 崩壊 域が大きくなっているが，石積みの到達距離は，それぞれ $6.8 \mathrm{~m}$, $6.9 \mathrm{~m}, 7.1 \mathrm{~m}$ でほぼ同等の值である。

上述のように，和庄小学校（No.16，17）の解析では，定性的， 定量的にもほぼ同様の結果が得られ，本研究における解析モデルの 範囲内では，地山が石積み擁壁に与える影響は小さいものであると 


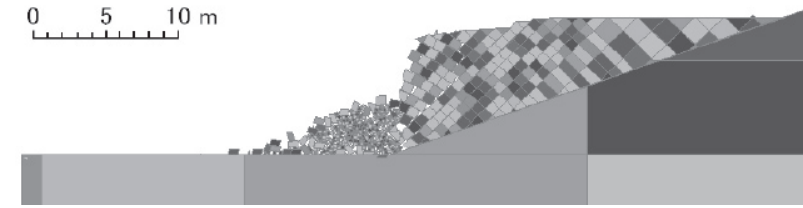

図 11 長迫小学校（No.27）残留変形図

考えられる。本研究では，ハザードマップ作成のために全 81 ケー スの石積み擁壁に対寸る DDA に基づく耐震性評価が必要で, 解の 安定性, 所要計算時間の観点から，4章の個々の石積み擁壁の耐震 性評価における解析モデルは, 後方地山を削り石積み擁壁周辺の地 山のみを残したものとする。

\section{4. 石積み擁壁の耐震性評価}

本章では, 中央地区の主要通学路域に既存する 81 箇所の石積み 擁壁に対する耐震性評価を行う。解析に用いる地震動は, 3.3 に示 す個々の擁壁位置での想定地震動である。残留変形事例を図 11 に, 耐震性評価結果を表 4 に示寸。ただし, 表記項目は, 石積み擁壁が 崩壊したものを危険箇所 $(\times)$, 崩壊には至らずはらみ出しを生じた ものを注意箇所 $(\triangle)$, 解析前後で変化のなかったものを安全箇所 （○）とする。また，石積みが崩壊したものであっても，道路幅員 に対し飛散していない領域が $2 \mathrm{~m}$ 以上あれば，避難経路としての機 能を有するものとする。ここで, 表中において, 和床小学校 (No.18) に関しては，石積みの崩壊はないものの腹み出しを生じており，擁 壁前面の道路幅員が $1.6 \mathrm{~m}$ と狭いことから交通機能性を有せず，ま た, 明立小学校（No.62）については、はらみ出しと崩壊の中間の 変形をしたため、安全性は低いと判断した。

解析の結果，表 4 に示すように，81 箇所の石積み擁壁のうち, $25 \%$ の 20 䇢所が “崩壊”, $61 \%$ の 50 箇所が “はらみ出し”, $14 \%$ の 11 籄所が “変化なし”という耐震性評価が得られた。ここで，2001 年の芸予地震の際に, 石積み擁壁の被害が集中したことが報告され ている鉢巻山の東傾斜面に位置する, 呉中央小学校, 両城小学校の 5 箇所の石積み擁壁では，3 箇所が “崩壊”，2 箇所が “はらみ出し” という結果が得られた。よって, 該当する石積み擁壁は危険性が高 いと言えよう。

一方, 避難経路としての機能面からは，石積み擁壁が崩壊した際 に前面の道路が遮断され，交通機能を維持できないものが 15 箇所 存在すると想定される。

\section{5. ハザードマップ}

本章では，3章での石積み擁壁の耐震性評価結果をもとに，石積 み擁壁の安全性と避難経路としての機能性に対するハザードマップ を作成する。それぞれのマップ例を図 12 , 図 13 に示す。

図 12 より, 明立小学校の主要通学路には, 崩壊が危惧される石 積み擁壁が点在し，また，崩壊には至らないまでもはらみ出しを生 じる石積み擁壁も多く，日常小学生が通学路として利用することは 危険であることが分かる。一方, 避難経路に関しては, 図 13 より, 和庄小学校では, 地震時避難経路としての機能を維持できず，避難 場所に到達寸るのに大きく迂回する必要があることが確認される。 ちなみに，その他の小学校のハザードマップにおいても，避難経路
表 4 石積夕擁壁の耐震性評価結果

\begin{tabular}{|c|c|c|c|c|c|}
\hline 学校名 & 番号 & 道路幅員（m) & 到達距離（m） & 安全性 & \begin{tabular}{|c} 
経路として \\
の機能性
\end{tabular} \\
\hline \multirow{3}{*}{ 呉中央小 } & 1 & 4.1 & 6.2 & $x$ & $\times$ \\
\hline & 2 & 4.4 & 0.0 & $\triangle$ & 0 \\
\hline & 3 & 19.3 & 5.4 & $x$ & 0 \\
\hline \multirow{9}{*}{ 本通小 } & 4 & 5.0 & 0.0 & $\triangle$ & 0 \\
\hline & 5 & 5.3 & 0.0 & $\triangle$ & 0 \\
\hline & 6 & 3.4 & 0.0 & $\triangle$ & 0 \\
\hline & 7 & 3.1 & 0.0 & 0 & 0 \\
\hline & 8 & 5.0 & 0.0 & $\triangle$ & 0 \\
\hline & 9 & 5.5 & 0.0 & $\triangle$ & 0 \\
\hline & 10 & 5.3 & 0.0 & 0 & 0 \\
\hline & 11 & 2.7 & 0.0 & $\triangle$ & 0 \\
\hline & 12 & 3.2 & 0.0 & 0 & O \\
\hline \multirow{10}{*}{ 和庄小 } & 13 & 8.6 & 0.0 & $\triangle$ & 0 \\
\hline & 14 & 8.4 & 0.0 & 0 & 0 \\
\hline & 15 & 6.7 & 6.8 & $x$ & $x$ \\
\hline & 16 & 4.2 & 0.0 & $\triangle$ & 0 \\
\hline & 17 & 4.0 & 8.3 & $x$ & $x$ \\
\hline & 18 & 1.6 & 0.0 & $\triangle$ & $x$ \\
\hline & 19 & 5.2 & 0.0 & $\triangle$ & 0 \\
\hline & 20 & 5.1 & 0.0 & $\triangle$ & 0 \\
\hline & 21 & 7.6 & 0.0 & $\triangle$ & 0 \\
\hline & 22 & 7.7 & 0.0 & $\triangle$ & 0 \\
\hline \multirow{4}{*}{ 辰川小 } & 23 & 4.5 & 0.0 & $\triangle$ & 0 \\
\hline & 24 & 2.4 & 0.0 & 0 & 0 \\
\hline & 25 & 3.2 & 0.0 & $\triangle$ & 0 \\
\hline & 26 & 3.5 & 4.9 & $x$ & $x$ \\
\hline \multirow{8}{*}{ 長迫小 } & 27 & 11.3 & 8.2 & $x$ & 0 \\
\hline & 28 & 4.6 & 4.6 & $x$ & $x$ \\
\hline & 29 & 7.1 & 4.5 & $x$ & 0 \\
\hline & 30 & 7.6 & 5.7 & $x$ & $x$ \\
\hline & 31 & 3.1 & 0.0 & $\triangle$ & 0 \\
\hline & 32 & 9.0 & 0.0 & $\triangle$ & 0 \\
\hline & 33 & 5.6 & 0.0 & $\triangle$ & 0 \\
\hline & 34 & 6.6 & 0.0 & $\triangle$ & 0 \\
\hline & 35 & 4.7 & 0.0 & $\triangle$ & 0 \\
\hline & 36 & 3.7 & 0.0 & $\triangle$ & 0 \\
\hline & 37 & 2.6 & 0.0 & $\triangle$ & 0 \\
\hline 莣袖町 & 38 & 2.7 & 6.0 & $x$ & $x$ \\
\hline ル神叮 & 39 & 2.7 & 0.0 & $\triangle$ & 0 \\
\hline & 40 & 2.3 & 0.0 & $\triangle$ & 0 \\
\hline & 41 & 3.3 & 12.3 & $x$ & $x$ \\
\hline & 42 & 2.9 & 0.0 & $\triangle$ & 0 \\
\hline 兩城小 & 43 & 5.5 & 0.0 & $\triangle$ & 0 \\
\hline 多 & 44 & 5.8 & 1.0 & $x$ & 0 \\
\hline & 45 & 3.4 & 0.0 & $\triangle$ & 0 \\
\hline & 46 & 2.3 & 0.0 & $\triangle$ & 0 \\
\hline & 47 & 2.9 & 0.0 & 0 & 0 \\
\hline & 48 & 2.8 & 0.0 & $\triangle$ & 0 \\
\hline & 49 & 2.5 & 5.0 & $x$ & $x$ \\
\hline & 50 & 3.5 & 8.0 & $x$ & $x$ \\
\hline 明立小 & 51 & 3.8 & 0.0 & 0 & 0 \\
\hline & 52 & 3.2 & 0.0 & $\triangle$ & 0 \\
\hline & 53 & 3.3 & 0.0 & 0 & 0 \\
\hline & 54 & 3.6 & 0.0 & $\triangle$ & 0 \\
\hline & 55 & 5.0 & 0.0 & 0 & 0 \\
\hline & 56 & 4.8 & 1.0 & $x$ & 0 \\
\hline & 57 & 3.4 & 0.0 & $\triangle$ & 0 \\
\hline & 58 & 2.6 & 0.0 & $\triangle$ & 0 \\
\hline & 59 & 2.9 & 0.0 & $\triangle$ & 0 \\
\hline & 60 & 4.1 & 0.0 & $\triangle$ & 0 \\
\hline & 61 & 3.7 & 0.0 & 0 & 0 \\
\hline & 62 & 5.9 & 0.0 & $x$ & 0 \\
\hline 明立小 & 63 & 4.1 & 0.0 & $\triangle$ & 0 \\
\hline & 64 & 4.4 & 3.0 & $x$ & $x$ \\
\hline & 65 & 2.9 & 0.0 & $\triangle$ & 0 \\
\hline & 66 & 3.0 & 0.0 & 0 & 0 \\
\hline & 67 & 3.3 & 0.0 & $\triangle$ & 0 \\
\hline & 68 & 7.1 & 0.0 & $\triangle$ & 0 \\
\hline & 69 & 18.5 & 0.0 & $\triangle$ & 0 \\
\hline & 70 & 5.0 & 0.0 & $\triangle$ & 0 \\
\hline & 71 & 4.6 & 4.0 & $x$ & $x$ \\
\hline & 72 & 4.7 & 0.0 & $\triangle$ & 0 \\
\hline & 73 & 4.5 & 5.5 & $x$ & $x$ \\
\hline & 74 & 4.0 & 0.0 & $\triangle$ & 0 \\
\hline 片山小 & 75 & 4.1 & 3.3 & $x$ & $x$ \\
\hline & 76 & 4.8 & 0.0 & $\triangle$ & 0 \\
\hline & 77 & 4.2 & 0.0 & $\triangle$ & 0 \\
\hline & 78 & 3.5 & 0.0 & $\triangle$ & 0 \\
\hline & 79 & 3.5 & 0.0 & $\triangle$ & 0 \\
\hline & 80 & 4.0 & 0.0 & $\triangle$ & 0 \\
\hline & 81 & 3.9 & 0.0 & $\triangle$ & 0 \\
\hline
\end{tabular}




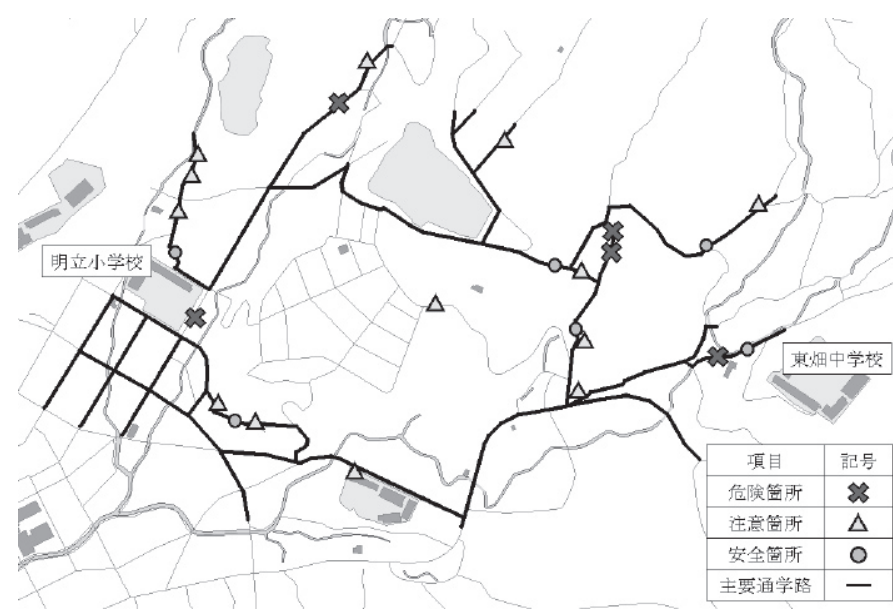

図 12 明立小学校 ハザードマップ（石積み擁壁被害）

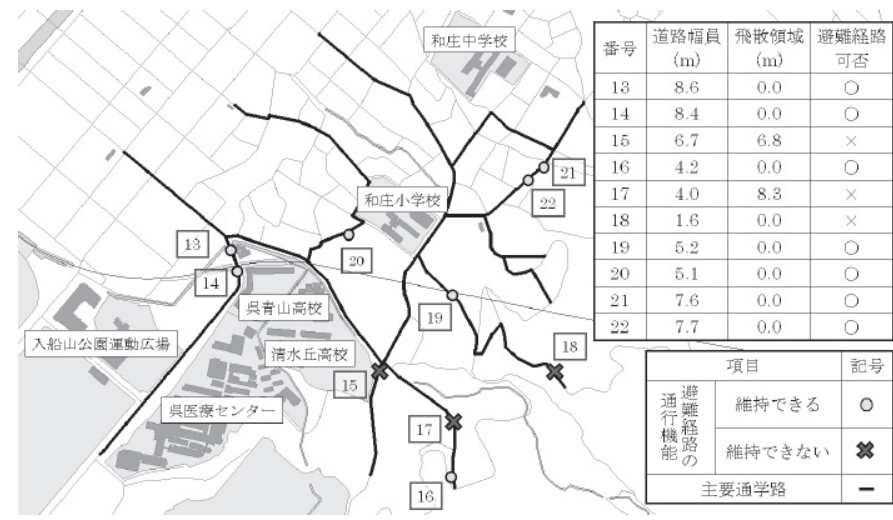

図 13 和庄小学校 ハザードマップ (避難経路)

が遮断され孤立状態になる地域が複数存在しており, 今後, 石積み 擁壁の耐震補強等の検討が必要であると考える。

\section{6. 結論}

本研究では, 通学路における危険箇所を抽出し, 避難経路として の安全性を検討することを目的として, 尅市中央地区小学校の主要 通学路域に既存する 81 箇所の石積夕擁壁の耐震性の評価, ならび に, 耐震性評価に基づくハザードマップの作成を行った。下記に研 究成果を示す。

(1)小学校の主要通学路域に対して写真測量等を伴う現地調查を行い, 81 箇所の石積み擁壁について擁壁の高さ, 平均勾配, 前面道路の 幅員, 擁壁構造についてデータを取得した。

(2)DDA による石積み擁壁の耐震性評価において, 石積み擁壁後方 の地山を含む解析モデル, 後方の地山を削った解析モデル, 下部 の地山を削った解析モデル, の 3 パターンの解析モデルに対して 解析を行った。その結果，いずれのモデルも定性的，定量的にほ ぼ同等の変形, 崩壞現象を起こしており, 本研究で行った程度の 解析モデルの簡略化は, 石積み擁壁の崩壊に対寸る影響は軽微で あると考えられる。

(3)小学校 9 校の主要通学路域におけるハザードマップより, 本通小 学校を除く小学校の主要通学路に崩壊が危惧される石積み擁壁が 点在している。また, 本通小学校, 両城小学校の 2 校以外の小学 校では, 避難経路としての利用が困難になると予想される通学路
が存在し，一部避難経路が遮断され孤立状態になる地域も確認さ れたことから, 今後, 石積み擁壁の耐震補強等の検討が必要であ ると考える。

最後に，本研究で作成したハザードマップを呉市教育委員会に提 示する予定であり，小学校の通学路，避難経路の見直しや，崩壊が 危惧される石積み擁壁の耐震補強にも活用してもらいたいと考えて いる。

\section{謝辞}

本研究を行うに当たり, 広島工業大学工学部の元学部生 三島康 寬氏，長見陽仁氏，田邊俊博氏には，測量調査等で多大なご協力を 戴いた。京都大学大学院工学研究科 西山哲准教授, 元京都大学大 学院生 赤尾悟史氏には深夜まで DDA の解析に関して懇切丁寧な ご指導を頂いた。芸予地震の石積み擁壁に関して広島大学大学院工 学研究科 加納誠二助教に貴重な情報, 資料の提供を頂いた。呉市 役所には中央地区の小学校の通学路マップを, 広島県には想定地震 の加速度応答スペクトルをご提供頂いた。また，想定地震波形の位 相は K-NET 呉の地震記録を使用した。ここに関係各位に謝意を表 する。

\section{参考文献}

1)田中邦熙, 新谷洋二, 山田清臣：石垣の安定性に関寸る各種の判定手法の 比較検討，土木史研究，第 18 号，pp. 139-152，1998

2) 渡嘉敷直彦, アイダンオメル, 大洞光央, 赤木知之 : 石積み擁壁の動的安 定性に関する実験および解析的検討, 第 35 回岩盤力学に関するシンポジウ ム講演論文集，No. 22，pp. 115-120，2006

3) 田中邦熙, 山田清臣：石積多擁壁の安定性評価, 土木学会論文集, No. 541/III-35，pp. 9-20， 1996

4) 鈴木智貴，若井明彦，平出務，源田真宏 : 石積夕擁壁の耐震性能を定量化 するための基礎的研究, 第 43 回地盤工学研究発表会講演集, pp. 1385-1386, 2008

5) 若井明彦 : 石積み擁壁の耐震性評価を目的とした動的弹塑性 FEM の拡張の ための基礎的研究, 第 61 回土木学会年次学術講演会講演概要集, 第 III 部 門, pp. 907-908, 2007

6) 池谷清次, 梁川俊晃, 西山哲, 関文夫 : 石積み擁壁の道路構造物への適用 に対する課題と展望, 土木計画学研究講演集, Vol. 29, 2004 (CD-ROM)

7) 西山哲, 大西有三, 大津宏康, 西村浩史, 梁川俊晃, 亀村勝美, 関文夫, 池谷清次: 不連続変形法（DDA）による石積み擁壁の安定性に関する研究, 地盤工学会, 第 38 回地盤工学研究発表会発表講演集, pp. 1631-1632, 2003

8) 国土交通省: 石積み擁壁の高さに関寸る法, 国土交通省告示第 383 号く土砂 災害特別警戒区域〉, http://iisee. kenken. go. jp/staff/tamura/work/ 1-1shikichi/383. html, 2009. 1. 28.

9) 赤尾聡 : 不連続変形法による岩盤斜面の地震応答解析に関寸る研究，京都 大学大学院工学研究科都市環境工学専攻修士論文, pp. 72-82, 2008

10) 大西有三, 佐々木猛, Gen-Hua shi, 不連続性岩盤解析実用化研究会: 不 連続変形法 (DDA)，計算レクチャーシリーズ 6, 丸善，2005

11）森川誠司, 田部井和人, 礒岩和夫, 田口勝則, 高橋晖雄, 石川典男, 西 村元男, 宮城重道, 二階堂聡 : 不連続変形法による城郭石垣の地震時安定 性に関する検討，第 38 回地盤工学研究発表会，pp. 1633-1634，2003

12) 関博, 伊藤興一，笹原克夫，吉中龍之進，進士正人：落石防護工設計一の 不連続変形法の適用, 第 26 回岩盤力学に関する講演論文集, pp. 391-395, 1995

13）立花規弘，本村将司：落石対策工事設計における DDA 解析の適用例，第 36 回地盤工学研究会, pp. 2511-2512, 2001

14）広島県県民生活部危機管理局危機管理室: 広島県地震被害想定調查報告書, 2007

15) 日本建築学会 2001 年芸予地震災害調査委員会 : 2000 年鳥取県西部地震災 害調查報告, 2001 年芸予地震災害調査報告, 日本建築学会，p. 258，2001

（2009年 3 月11日原稿受理，2009年 8 月12日採用決定） 